\title{
Social Solidarity Economy and Sustainable Development: Bringing global challenge to Indonesia
}

\author{
Aliah B. Purwakania Hasan \\ Department of Psychology \\ Universitas Al Azhar Indonesia \\ Jakarta, Indonesia \\ aliah@uai.ac.id
}

\begin{abstract}
In achieving sustainable development goals, the mainstream economic paradigm needs to be adjusted to resolve social and environmental costs of production and consumption that have been address as externalities. For this, the social and solidarity economy (SSE) is seen as a specific approach, because of its historical position in integrating social, economic and environmental missions; and due to its rootedness in real world practices that challenge the global neoliberal and market oriented hegemony. The SSE can be consider as growing social movement, which includes a range of program and activities that share common values, primarily solidarity and mutual support, that focus on community level development. The aim of this article is to explain how SSE may prove beneficial, both in concept and in practice, towards more sustainable development. Towards this, the evolution of the SSE will be explained in differing cultural contexts. As discussion, Indonesia context were also described.
\end{abstract}

Keywords-environmental based community development; social and solidarity economy; sustainable development;

\section{INTRODUCTION}

On 30 September 2013 in Geneva, the founding meeting of the UN Inter-Agency Task Force on Social and Solidarity Economy (SSE) took place [1]. This is a new inter-agency partnership to assist countries, mobilize political will and enhance momentum towards mainstreaming issues of SSE in local, national, and international policy frameworks. The international development community emphasizes the need to rethink development. Business-as-usual has not been preventing the recent persistent poverty, financial and food crises, climate change, and economic inequality. For future development agenda, it will be important to considering Social and Solidarity Economy (SSE) as a pathway to sustainable development [2].

UN Task Force on Social \& Solidarity Economy (UNSSE) was found to actuating SSE visions in international policy and science network [3]. According to this congress, SSE holds considerable and potential promise for addressing sustainable development in economic, social and environmental integrated circles. UNSSE mission is to bring together UN agencies and other inter-governmental organizations as umbrella associations of SSE networks for its members and observers. UNSSE works include organizing events at UN and delivering other international conferences, preparing and disseminating publications, dialoguing with policy makers, and engaging in collaborative projects involving UNSSE members and observers.

Nowadays, the social and solidarity economy (SSE) has gained prominence as conceptual and practical critiques to the free market ideology and unfettered capitalism [4]. SSE is a field of work and research that focuses on economic activity that factors in social and environmental line, often organized with values and principles of solidarity, co-operation, transparency, and other ideas that prioritize social well-being. The SSE broadens the discourse beyond a unidimensional, economy market-centered view, that showing the diversity of practices in production, consumption and distribution. SSE across the world can be perceived in action, often with remarkable results in community-building, providing decent work and empowerment, and preserving the environment at the same time. SSE can be considered as an increasingly important pathway towards sustainable development [5]

\section{SOCIAL SOLIDARITY ECONOMY APPROACH}

United Nations World Commission on Environment and Development [6] defines sustainable development as development that meets the needs of the present without compromising the ability of future generations to meet their own needs. The notion of sustainability has three intertwined components: social, economic, and environmental sustainability, reflecting that sustainable development needs to balance social inclusion, economic distribution and environmental protection.

Not all approaches to sustainable development have same perspective. As elaborations in Table 1, UNRISD (2012) explains four different worldviews of sustainable development with their associated pathways [3]:

- The market liberal worldview argues that economic growth would provide improved capacity to make environmental 
improvements, and hence advocates for capitalism with a green facell as a solution.

- The institutionalism worldview shares the capitalist ideology, but with stronger emphasis on redistribution of income and the role of states and global governance, and sees the solution in strong sustainability.

- In the social green worldview, social, economic and environmental problems are seen as intertwined, and therefore the restructuring of capitalism is required to balance global inequalities. Social economy is seen as the pathway.

- For the bio-environmental worldview, the earth's limited ecological carrying capacity is emphasized, along with its inability to support infinite economic growth. For this worldview, the limits to growth solution is the way to go, in drastically revamping the economic system to achieve sustainable development.

As seen in Table 1, the social economy pathway (and the solidarity economy as well, as it has similar standpoints) addresses social, environmental and economic pillars with a strong sense of social empowerment and environmental justice, as well as refocusing the economy on the local. While it is more pragmatic than a limits to growth approach, which would be much harder to implement effectively, it takes a more radical approach than the first two pathways.

Table 1. Four different worldviews of sustainable development

\begin{tabular}{|c|c|c|c|c|}
\hline Pathways & $\begin{array}{c}\text { Capitalism } \\
\text { with a green } \\
\text { face }\end{array}$ & $\begin{array}{c}\text { Strong } \\
\text { sustainability }\end{array}$ & $\begin{array}{c}\text { Social } \\
\text { economy }\end{array}$ & $\begin{array}{l}\text { Limits to } \\
\text { growth }\end{array}$ \\
\hline $\begin{array}{l}\text { World } \\
\text { view }\end{array}$ & Market liberal & Institutionalist & Social green & $\begin{array}{l}\text { Bio- } \\
\text { environmental }\end{array}$ \\
\hline $\begin{array}{l}\text { Time } \\
\text { frame }\end{array}$ & Short-medium & Medium & Short and long & Long \\
\hline $\begin{array}{l}\text { Environ- } \\
\text { ment }\end{array}$ & $\begin{array}{l}\text { Green jobs } \square \\
\text { Social } \\
\text { protection for } \\
\text { vulnerable } \\
\text { groups } \\
\text { Equality of } \\
\text { opportunity } \\
\text { Consultation } \\
\text { Green } \\
\text { Consumerism }\end{array}$ & $\begin{array}{l}\text { Global } \\
\text { cooperation } \\
\text { Redistribution } \\
\text { (income) } \\
\text { Stronger } \\
\text { institutions } \\
\text { Inter- and } \\
\text { intra- } \\
\text { generational } \\
\text { equity } \\
\text { Capacity } \\
\text { building } \\
\text { Social } \\
\text { dialogue }\end{array}$ & $\begin{array}{l}\begin{array}{l}\text { Redistribution } \\
\text { (power) }\end{array} \\
\text { Rights-based } \\
\text { Social justice } \\
\text { Equality of } \\
\text { outcomes } \\
\text { Empowerment } \\
\text { Citizen action }\end{array}$ & $\begin{array}{l}\text { Radical } \\
\text { decrease in } \\
\text { consumption } \\
\text { and population } \\
\text { growth } \\
\text { Inclusivity } \\
\text { Needs } \\
\text { Rights }\end{array}$ \\
\hline Economy & $\begin{array}{l}\text { Green growth } \\
\text { Voluntary } \\
\text { CSR } \\
\text { Carbon } \\
\text { market, PES. } \\
\text { Production- } \\
\text { focused } \\
\text { Private } \\
\text { governance }\end{array}$ & $\begin{array}{l}\text { Economic/trad } \\
\text { e reform } \\
\text { Green finance } \\
\text { Green taxes } \\
\text { State } \\
\text { governance } \\
\text { CDM }\end{array}$ & 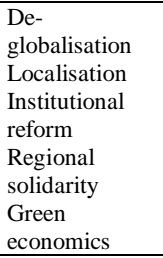 & $\begin{array}{l}\text { No-growth/de- } \\
\text { growth } \\
\text { Measure } \\
\text { beyond GDP } \\
\text { Ecological } \\
\text { economics }\end{array}$ \\
\hline $\begin{array}{l}\text { Represen- } \\
\text { tative } \\
\text { organisa- } \\
\text { tions }\end{array}$ & $\begin{array}{l}\text { WTO, IMF, } \\
\text { WBCSD }\end{array}$ & $\begin{array}{l}\text { UNEP, } \\
\text { UNFCCC, } \\
\text { Global } \\
\text { Environment } \\
\text { Facility }\end{array}$ & $\begin{array}{l}\text { World Social } \\
\text { forum, Third } \\
\text { World } \\
\text { Network }\end{array}$ & $\begin{array}{l}\text { World Watch } \\
\text { Institute, } \\
\text { Pachamama }\end{array}$ \\
\hline
\end{tabular}

A strong capitalistic model, even with a green face, still draws heavily from market logic and infinite growth, with profit-making trumping all other goals. As for the institutionalism approach, there are concerns regarding the legitimacy and capacity of existing or reformed institutions across the world, especially in the era of trade regimes, elite power, corporate influence in macro-economic policy, and such.

The social economy approach also has specific weakness. According to UNRISD [5], many challenges to the social economy include fragmentation, the political strength of interests pushing for business-as-usual, the lack of a widespread social base for focusing on ethics and justice, and the difficulties to organize global movements. Thus, the social economy receives paltry attention when it comes to funding, research and policy work in this field. Therefore, although this approach has potentials in effecting real change at a structural level, a lot of works still needs to be accomplished if the SSE is to be a pathway towards sustainable development.

Elaborating further SSE potential for sustainable development, the UN Task Force for SSE gathers eight themes in which the SSE is able to play an integrative role in addressing economic, social and environmental objectives within the context of sustainability. These themes are transitioning from informal economy to decent work, greening the economy and society, local economic development, sustainable cities and human settlements, women's well-being and empowerment, food security and small-holder empowerment, universal health coverage, and transformative finance. The rootedness of SSE in real practices presents it as a viable model of transformative change, in comparison with models based on utopian idealism or blueprints; and the real world experiences also contribute empirical lessons back to the theory of change, countering neoliberal hegemony in the policy and public space [5].

SSE is an important vehicle towards sustainable development because of its historical position of addressing the overlaps and trade-offs in between social and economic pillars. Through experience, its proponents understand that inter-linking social and economic goals brings its strengths (when actors succeed in deriving both income and social benefits through well-designed processes) and also weaknesses (when difficult choices have to be made when social and economic bottom lines clash). The environmental factor that constitutes the third bottom line does not require a major paradigm shift, because protecting the environment is prerequisite to protecting human and societal well-being. The economy is seen as a tool towards social betterment and not an end in itself, which is congruent with the notion of environmental preservation for good quality of life for all beings, born and yet unborn.

\section{SOCIAL SOLIDARITY ECONOMY AS THIRD SYSTEM OF ECONOMY}

Nowadays, SSE theories and practices have different forms from the general social economy, in the aim towards systemic transformation of the economy, or as the part of 'counter-hegemonic political economy' [4]. Although, SSE 
activities traditionally grouped under the third sector or social economy, such as social entrepreneurship, SSE essentially different in set of its explicit core values that emphasize the importance of solidarity and mutual support to build a new economic paradigm. Increasingly seen as a social movement [7]. SSE differs with any single definition, but it can be generally understood as placing human beings at the center of economic and social life [8]. Therefore, SSE is more relevant to sustainable development, particularly at the community level, where many SSE activities take root.

The social economy, according to several observers [2], are seen as important or supportive part of capitalism, to mitigate social issues that result from inadequacies of the first and second system. However, others see it as an intermediary step towards transformation of existing economic system that prizes profits and growth above all. Thus, solidarity economy has a much clearer vision in achieving a transformed economic system that involves all three systems of the economy towards a post-capitalist agenda that works for social welfare under the constraints of nature limitations. As shown in Figure 1, the solidarity economy starts from a local level and expand to the circle of solidarity that encompasses the private, public, and third sector.

Fig 1 Social economy in the three systems of the economy

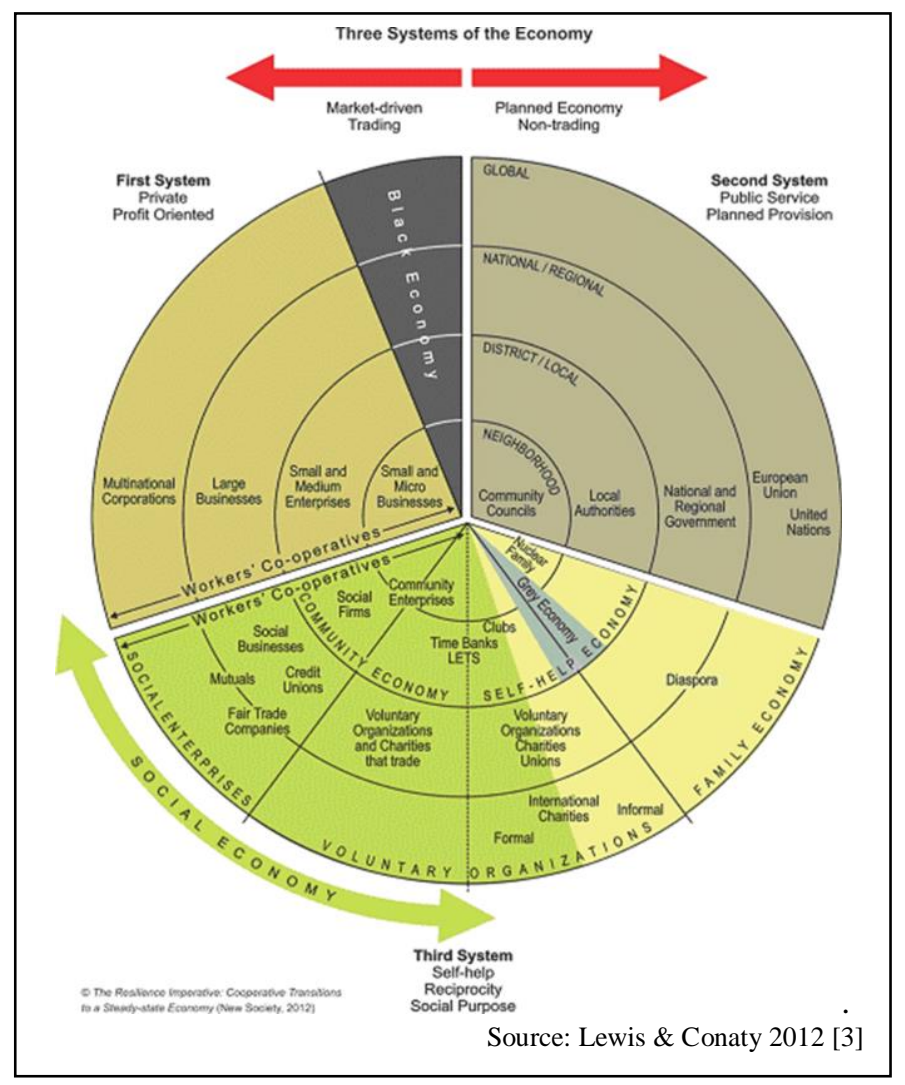

The SSE, due to its nature boundaries and conceptualisations, is vulnerable to the opening up the discursive space for what appears to be less socially oriented policies, initiated by opportunistic actors [9]. As the sector has explicit social goals, it enables the government to view it as a development panacea and a reason for reducing social service provision. On the other side, the private sector comes in with the perspective of doing social good when it makes business sense, but choosing profitability over social aims when it does not. Therefore, it is important to understand the normative values and principles that form the SSE's foundations.

\section{SOCIAL SOLIDARITY ECONOMY AS THIRD SYSTEM OF ECONOMY}

The SSE builds on social economy, traces its roots to the early period of industrialization in Europe. This social economy has been relegated to the status of a 'third sector' in the post-war period, but at a time when market economies were seen as the primary vector for regulating labors, currencies, and property, while the state had responsibility for social action through the redistribution of wealth [10]. The revival of interest in the social economy in the 1980s and 1990s, in Europe and Latin America, has taken on a more ambitious form, in light of the failure of current forms of development, which actually have proved to be un-sustainable. Widening inequalities and environmental ails, within countries and at a global scale, attest to the weaknesses of the sustainable development paradigm and, more generally, what has been called a crisis of values [10].

History of social economy in Switzerland has followed a similar path to Western Europe. At the end of the nineteenth century, laws were created to formalize the legal status of associations, cooperatives and other social organization types. The social economy then merged with the dominant market economy in period between the Second World War and the start of the twenty first century, during which a great number of cooperatives were transformed into capitalist corporations. Those who were able to maintain their legal status as a cooperative often had to relinquish much of their social missions in order to remain competitive [10]. Since the 1970s, there has been renewed interest in the social economy and a broadening of its vision to include ecological considerations, towards the SSE, as interpreted in Geneva today.

In the 1990s, new organizations emerged to address a series of issues, including the exclusion of persons with disabilities from the economy; rising unemployment rates in Europe (1980s) and Switzerland (1990s); more women in the workforce and the need for childcare services; an ageing population and the need for socially oriented medical establishments; and negative environmental impacts, such as pollution, resulting from economic development. In the same period, a number of new, not-for-profit organizations emerged as part of a vibrant civil society in Switzerland. The social economy born in the nineteenth century and dominated by cooperatives and mutual societies in Europe [12] thus expanded to include other types of legal entities, such as notfor-profits, associations, philanthropic organizations such as foundations, and corporations. 
The SSE was born in Western Switzerland in the early 2000s through the emergence of work integration social enterprises and the creation of new cooperatives, as well as communication campaigns by social and solidarity networks. In 2006, the first SSE Chamber of Commerce in Switzerland was established in Geneva, called APRES-Geneve. That time, understanding to what extent the SSE contributes for the national economy is still difficult to predict. There was only a little national data exist on the SSE, although researches are currently underway [13]. In Geneva, about 10 per cent of employment is based on the SSE.

Currently, the Geneva SSE Chamber counts 260 member organizations that are engaged in all forms of economic activity, including financial services, adult education, cooperative housing, local agriculture, education, work integration, construction, community services and fair trade. Some organizations are small in size, while others count several hundred workers. The process of federating different organizations in Geneva took place around shared values and concrete practices and was initiated by local actors who participated in the Second World Social Forum in Brazil (2002), where they recognized the importance of networks in supporting SSE organizations towards a new economy. The majority of current APRES-Geneve members existed prior to the creation of that chamber, which means that they had already been practicing social and solidarity economic activities, sometimes for several decades, without necessarily seeing themselves as part of a movement.

Geneva has organized itself into a membership network of SSE organizations, and that efforts are also starting in Metro Manila. The approach in Geneva has been to make a value system explicit through guiding principles and encourage members in the SSE Chamber to progressively put those principles into practice [14]. Efforts have been very inclusive in terms of bringing on board a variety of actors from different product and service sectors, towards a multidimensional SSE landscape, as well as raising awareness around the SSE to elected officials and the general public. While Geneva is a small city, SSE actors offer a range of products and services, which are seen as directly benefiting the community and setting an example in the region.

However, the SSE movement in Geneva seems to focus more on the practice of individual members. It could be more benefit from a conceptual approach, where the SSE has potentials to transform the entire economy, across different sectors, and moving beyond a focus on the enterprise itself. This perspective is more closer to the Philippines SSE movement, that conceptualized as an umbrella concept that view economy as a whole, but operations primarily to engage with the poor as primary stakeholders. Much of the SSE activity in the Philippines is focused on the rural context, specifically on farmers, with little actors identified in urban areas, or in service sectors such as housing, transport or insurance. While SSE based on community initiatives are learning to work across supply chains, what remains to playing out in the consecutive years. The challenge will make
SSE services and products available across different sectors and communities, in order to bring social benefits for broader regions. This requires strong leadership and reaching out to organizations, which do not necessarily understand themselves as part of the SSE today.

The main issue in both Manila and Geneva is that of coherence, not only within an organization, in terms of its mission and how this plays out in every-day operations, but also coherence when working with other organizations [15]. Through case studies, we had gleaned what may be certain pitfalls in this respect, including: organizations may not be aware of other SSE offers that could be complementary to their own; such offers may not be available (in terms of quality and quantity), or not affordable. What may be more important is the possibility of moving progressively towards maximum coherence, as well as the broader issue of whether organizations see themselves as part of a need for wider systemic change across the economy; in Geneva, this may not be the case for all SSE members, who are not necessarily seeking to change the capitalist system; in the Philippines, the current focus on the rural sector may not suffice in the longterm, with more action necessary in urban centers and across sectors [16].

The SSE is model of economy sustainability, an economy with a market, guided by social and ecological values. It brings activities that tend to grow at the community level towards more sustainable forms of development, while environmental values could be strengthened further. The different social forums and SSE networks are paving the way for better collaboration across communities and regions. However, a link remains to be made between the solidarity economy and environmental forums. The SSE movement might benefit to be a systems approach embraced by strong actors in sustainability research, especially thinkers from industrial ecology who might better mimic the efficiencies found in nature [17]. In turn, researchers in the environmental sustainability community could benefit from the conceptualization of economy that places people and earth first, and in solidarity as explicit value both conceptually and practice in the SSE, bringing a more systemic understanding between society, economy and environment towards transformative SSE culture.

The SSE is operating in very different realities across context and culture. Example, while democratic processes are taken for granted by Swiss citizens, there is a need to move towards a further democratization of the economy in the Philippines. While in western contexts, certain people continue to press for an overall reduction in consumption and production (also known as the 'de-growth' debate), there are many millions of people in the Philippines for whom the consumption of additional resources is not a matter of greed, but of need. The SSE certainly seems to be a stepping-stone towards more socially just and environmentally sound world but, in order to get there, greater solidarity is needed not only across supply chains and between SSE actors, not only between the SSE movement and those working in the area of 
environmental sustainability, but also greater solidarity between communities and regions in a highly unequal world.

\section{DISCUSSION}

Indonesia has different conditions with other countries. However, there are at least two things, which show that Indonesia, consciously or unconsciously, has actually implemented the SSE movement, the Pancasila democratic economic system, and the cooperative as a state backed bone business movement. However, the concept of SSE becomes more comprehensive, through its concept, support not only social solidarity, but also to the environmental economy, to achieve sustainable development. Nevertheless, the clearness of state involvement in the SSE movement can only be seen when the state participates actively, in the form of policy or practice at the local, national and international levels.

Learning from the case of Switzerland, as the driving force behind the birth of this movement, SSE can grow in a democratic country. Since the founding of the Republic of Indonesia, many state figures at that time have formulated the economic system for the Indonesian nation, both individually and in groups. In 1949 speaking in America, Sumitro Djojohadikusumo [18] asserted that the ideal system is a mixed economy, but in the process of development, it has been agreed upon a new economic form called Pancasila Economic System, which contains an important element that called Economic Democracy. According to him the system of Economic Democracy has positive characteristics, such as the economy is arranged as a joint effort on the principle of kinship, the branches of production that are important for the state and control the livelihood of the people managed by the state, citizens have freedom in selecting the occupation according to their wishes and has the right to work and to a decent living, private property is recognized and its use shall not be in conflict with the public interest, the potential, initiative and creativity of every citizen are fully developed within limits that do not harm the public interest, the poor and abandoned children maintained by the state.

Indonesia needs to keep striving to achieve substantive democracy in its economic system. However, the Indonesian economy does not allow for free fight liberalism, etatism and monopolism. In free fight liberalism, there is an uncontrolled freedom of that allows for exploitation of weak and colonized economies with the result in increasing gap between rich and poor. In the system of etatism, too much dominance of government turns off the motivation and creation of society to develop and compete healthily, people just be passive. In a monopoly system, there is a form of concentration of economic power in one particular group, thus giving no other choice to the consumer that different to the monopolist's wishes. However, the economic system of liberalism and etatism has happened in Indonesia. The early 1950s up to the 1957s is a historical proof of the existence of a liberal style in the Indonesian economy. Likewise with the system of etatism, had also colored the pattern of the economy in the 1960s until the new order.
Philippine is a country that runs SSE through cooperatives focused on the poor with state support. While in Indonesia, government policy, as mandated by the 1945 Constitution, actually opens wide opportunities for the development of cooperatives. Cooperative is a joint business entity, which based on the principle of populist economy based on the principle of kinship. Various advantages possessed by cooperatives such as cost efficiency as well as from increasing economies of scale clearly make the cooperative as a highly prospective business entity in Indonesia, including to solve the middle income trap problem with the development of green cooperative Indonesia as the base of SSE.

However, a quite dilemmatic phenomenon, although the cooperatives have various advantages and supports, they were still difficult to grow in Indonesia. The cooperatives were in comma for the last 15 years. Indonesian cooperatives were only standing still or even declining. The development of Indonesian cooperatives experienced ups and downs. In fact, the government's efforts to empower the cooperatives are never-ending. Even, it can be said, probably very indulgent. Various packages of government aid programs such as program credit: KKop, KUT (Farmer Credit), transfer of shares from large companies to Cooperatives, KUK program schemes from banks and Food Security Credit (KKP), which are commercial loans from banks, Civil National Capital (PNM), continues to flow to empower this populist economic movement. Not only the assistance of the program, there are special institutions that handle outside Indonesia Cooperatives Council, namely the State Minister of Cooperative Affairs and Small and Medium Entrepreneurs (PKM), which as a spur this movement to move forward. However, in reality, the Cooperative is still attached to the marginal economic stigma, the businessman who needs to be "pitied".

In order to develop SSE in Indonesia, it is necessary to pay attention to various causes of underdevelopment of cooperatives. The causes include:

\section{A. Lack of Member Participation}

The cooperatives member cannot better participate if they do not understand what cooperatives are. The result is that cooperative members do not show their participation either as a contributive or incentive to their own cooperative activities. The lack of education and training provided by the management to the members of the cooperative is suspected to be the main factor, since the board members assume it will not benefit them. Cooperative activities that do not develop make the source of capital becomes limited. The limited business is due to lack of support and contribution from its members to participate in making cooperatives such as stagnant. Therefore, all problems stem from the participation of members in supporting the formation of a formidable cooperative, and provide benefits to all its members, as well as the surrounding community. 


\section{B. Socialization of Cooperative}

The level of participation of members of cooperatives is still low, because socialization has not been optimal. Society members are only limited to know the cooperative is only to serve consumers as usual, whether for consumer goods or loans. This means that people do not yet know the essence of the cooperative itself, either from the capital system or the ownership system. They do not know very well that in consumer co-operatives also mean owners, and they are entitled to participate contribute suggestions for the advancement of their cooperatives and the right to oversee the performance of the board. Such circumstances are certainly very vulnerable to misappropriation of funds by the board, because without the participation of members there is no control of the members themselves against the board.

\section{Management}

Cooperative management should be directed to a strategic orientation and cooperative movement must have human beings capable of collecting and mobilizing the various resources needed to take advantage of business opportunities. Therefore, the cooperative must be careful in choosing management and managers for established business entities will develop well. The lack of professional management of cooperatives occurs in cooperative co-operatives whose members and administrators have low levels of education. For example many occur in KUD that in remote areas. There are so many KUDs that go bankrupt because the management is not professional either in the management system of its business, in terms of its human and financial resources. There are many KUDs that only serve as a place for corrupt officials of government aid funds.

\section{Capital}

The lack of development of cooperatives is also closely related to the condition of the financial capital of the business entity. Capital constraints that could be due to lack of strong capital support and in or even too dependent on capital and the source of the cooperative itself. Therefore, to get out of the problem must be done through a structural breakthrough, meaning the restructuring in the mastery of production factors, especially capital.

\section{E. Human Resources}

Many members, administrators and managers of cooperatives are less able to support the way of cooperatives. With this condition, the cooperative goes unprofessional in the sense that it is not executed in accordance with the rules as other businesses. In terms of membership, it is often based on the imposed impulses imposed by the government. As a result the establishment of cooperatives is based not from below but from above. Selected boards in member meetings are often chosen based on social status within the community itself. Thus the management of the cooperative is run by the lack of strict control of its members. Managers appointed by the board are often taken from the less professional. They do not have enough experienced both academic and application in entrepreneurship.

\section{F. Lack of Publice Awareness}

The development of cooperatives in Indonesia that started not bottom up but from the top down, meaning that the cooperative developed in Indonesia not from public awareness, but emerged from the government support that is socialized down. Unlike the overseas, the cooperative is formed because of the awareness of the community to help each other meet the needs and prosperity, which is the purpose of the cooperative itself, so that the government remains a supporter and protector only. In Indonesia, the government works double in addition to support should also be socialized first down so that people understand the benefits and goals of the cooperative.

\section{G. Pampering}

The government seems too pampering the cooperatives, this is also a strong reason why Indonesian cooperatives are not advanced. Many cooperatives are assisted by the government through fresh funds without any supervision of the aid. The nature of the aid is not mandatory to be returned. Of course this is a help that does not educate, cooperatives become "spoiled" and not independent just waiting for further assistance from the government. In addition to disadvantage of government assistance like this will, also make the cooperative cannot compete because it continues to continue to be parasitic country. The government should disburse aid with its good oversight system, although the funds are grants that do not need to be returned. Thus it will help the cooperative to become more professional, independent and able to compete.

\section{H. Less Economic Democracy}

In the sense of the word economic democracy is lacking this can be interpreted that there are still many cooperatives that are not given flexibility in running every action. Each cooperative should be able to freely provide services to the community, because the cooperative is very helpful to improve the level of people's welfare by all services - services provided, but it is very far from what they published. The flexibility undertaken by the cooperative body is still very low, it can be exemplified that the KUD cannot provide loans to the community in providing loans, for the business community itself without the approval by the district level etc. Therefore the cooperative should be given a little flexibility to provide service to its members more easily, without very difficult conditions.

The SSE, according to UNSSE, not only consists of cooperatives, but also includes organizations and companies that have explicit economic, social and environmental objectives; involves various levels and forms of cooperative, associative and solidarity relationships between workers, producers and consumers; practice workplace democracy and self-management. The SSE includes various traditional forms of cooperatives and reciprocal associations, as well as women's self-help groups, community forestry groups, social provision organizations or proximity services, fair trade organizations, informal sector workers associations, social enterprises, as well as societies of currency and alternative schemes financing. The weakness of cooperatives in Indonesia 
could be improved by developing cooperatives within the SSE network, so that cooperatives can learn from each other and strengthen other members of the network, especially to overcome the middle class income trap. Cooperatives in Indonesia must of course strengthen with the vision and mission of the environment so that the development of green cooperatives.

\section{CONCLUSION}

The SSE is quite prospective to be developed in Indonesia, refer to other countries, such as Switzerland and the Philippines. Switzerland is a democratic country that gave rise to a SSE system, while the Philippines is a country that develops this system through cooperatives focused on the poor to increase their income. In Indonesia, prior to the establishment of UNSSE, it has sought to develop a system of economic democracy and develop a cooperative system.

To develop SSE in Indonesia, it is necessary to develop environmentally friendly green cooperatives. Therefore, it is necessary to study the factors that hinder the progress of cooperatives in Indonesia. In general, problems faced by cooperatives can be grouped into 2 problems, namely internal problems and external problems.

Internal issues that occur include the administration of activities not meeting certain standards so as to provide data for decision-making is not complete; likewise the statistical data mostly lacks the need; with a relatively small business capital, The volume of business is limited, but if you want to increase the volume of activities, skills are not able to cope with large-scale business. Also because of low incentives so that people are not moved to run a complex big business. Due to the limited funds, there is no maintenance of facilities or machines, whereas technology is growing rapidly. This leads to relatively high cost of goods thereby reducing the competitiveness of cooperatives. Cooperative management is also a figure in the community, so that this "dual position" leads to the fact that the focus of attention on the management of the cooperative is reduced so as to be less aware of environmental changes. Most cooperative managers are too old, and their capacity is decreased. Mistrust of members of co-operatives causes difficulties. Most members lack solidarity to cooperate on the other hand members owe much to the cooperative.

External problems faced by cooperatives include increased competition from other business entities that freely enter the business field being handled by cooperatives; Due to the removal of certain facilities the cooperative can no longer run its business properly, for example the business of distribution of fertilizer which in the past distributed by cooperatives through cooperatives now no longer so forced to seek their own, the community's own response to the cooperative; Because of the failure of the cooperative in the past without any accountability to the community that caused a lack of trust in the community about the management of the cooperative; The ever-changing price level so that current sales revenue cannot be used to continue the business, just shrink the business.

The problems faced by the cooperative became relatively more acute, chronic, severe due to several reasons the fact that the boards or members of the cooperative were already familiar with the rationing system so that they used to be in production only, raw materials available, marketing already existing channels, "Sellers market" deals with government in implementing politics. Now the open economy system is characteristic of competition. It may take adjustment and this takes some time. Members and administrators may lack knowledge or skills in management. There should be an interest to develop them to appreciate the problems faced. Because of the narrow-mindedness of certain "manipulation" attempts, for example in the allocation of orders / tasks because of the small "opportunity available" people tend to use something for themselves first. For that, it is important to feel the loyalty of members; but because members try individually (no more trust in the cooperative), there is no time to communicate, there is no giving and receiving of information, there is no harmonious purpose between members and cooperatives and so on, so the problems faced by cooperatives can hinder the development of cooperatives.

SSE Network can make cooperative in Indonesia more developed. This network can develop cooperative capability and competitiveness. Through this network, cooperatives in Indonesia can be more environmentally sound, so it is expected to support the implementation of sustainable development.

\section{ACKNOWLEDGMENT}

This research was supported by International Seminar Grant LP2M Universitas Al Azhar Indonesia. I would like to thank all my colleagues that provided insight that assisted this research.

\section{REFERENCES}

[1] D. Jayasooria, Developments in the solidarity economy in Asia, JJ Resources, Asian Solidarity Economy Council, Centre for Social Entrepreneurship, Binary University, Malaysia, 2013

[2] E., Kawano, T. N. Masterson, and J. Teller-Elsberg, Solidarity Economy I: Building Alternatives for People and Planet. Center for Popular Economics, Amherst, MA, USA. 2009.

[3] E. Kawano, Social solidarity economy: toward convergence across Continental Divides. 2013 Available at: http://www.unrisd.org/unrisd/website/ newsview.nsf/\%28httpNews\%29/F1E9214CF8EA21A8C1257B1E003B 4F65? OpenDocument.

[4] V. Satgar, The Solidarity Economy Alternative: Emerging Theory and Practice, University of KwaZulu-Natal Press, Pietermaritzburg, South Africa. 2014.

[5] P. Utting, N. van Dijk, M.A Mathei. Social and Solidarity Economy. Is there a New Economy in the Making? UNRISD, August 2014

[6] United Nations World Commision on Environment and Development. Our Common Future. Oxford University Press. 1987

[7] J-F Draperi. L'Economie Sociale Et Solidaire. Paris: Dunod, 2011

[8] ISGC. International Solidarity Globalization Conference Lima Declaration. Lima: ISGC, 1997 
[9] J.J. McMurtry. The Cancer Stage of Capitalism: From Crisis to Cure, London: Pluto, 2013

[10] J.-L. Laville, A new European socioeconomic perspective, Review of Social Economy, LXI, 389-405. 2003.

[11] J-L. Laville, and A. D. Cattani, Dictionnaire de l'autre e'conomie, Gallimard, Folio actuel, Paris. 2006.

[12] A. Gueslin. L'invention de l'economie sociale. Paris: Economica, 1998.

[13] S. Swaton, Une Entreprise peut-elle etre sociale dans une ecnomie de marche? Charmey, La Question, 2011

[14] M.D., Sahakian, and C. Dunand, The social and solidarity economy towards greater sustainability: learning across contexts and cultures, from Geneva to Manila. Community Development Journal. 2014.
[15] M. D. Sahakian, A matter of trust in Metro Manila: collective action towards 'green economy' transitions, Development, 55, 126-133. 2012.

[16] NSCB. Full Year Official Poverty Statistics Republic of the Philippines, National Statistical Coordination Board, Metro Manila, The Philippines. 2013.

[17] S. Erkman, Industrial ecology: an historical view, Journal of Cleaner Production, 5, 1-10, 1997.

[18] Sudarsono. Manajemen Koperasi Indonesia. Jakarta: Rineka Cipta, 2010 